\title{
ALTERAÇÕES POSTURAIS EM IDOSOS DA REGIÃO DO VALE DO SINOS
}

Caroline Fagundes; Universidade Feevale; caroline@espacotao.net.br; Geraldine Alves dos Santos; Universidade Feevale; geraldinesantos@feevale.br

\section{RESUM0}

Introdução: Com o envelhecimento observa-se a redução das funções fisiológicas, incluindo alterações nos tecidos que envolvem as articulações. Essas modificações podem resultar em desconforto, dor e, em alguns casos, incapacidade funcional, influenciando de maneira negativa na autonomia dos idosos. Objetivo: Avaliar as alterações na postura estática em idosos da região do Vale do Sinos/RS. Método: Participaram dessa pesquisa 112 sujeitos, com idade entre 60 e 88 anos, distribuídos em 2 grupos. $\mathrm{O}$ grupo I formado por 55 indivíduos praticantes de hidroginástica e o grupo II composto por 57 idosos participantes de um programa de informática. Para a coleta de dados foi utilizado o Postural Assessment Software (SAPO). Resultados: Observou-se que $84,8 \%$ apresentavam assimetria da cabeça, $83 \%$ assimetria dos acrômios e 93,8\% joelho varo. Já nas vistas laterais, $100 \%$ da amostra apontava anteriorização da cabeça, 93,8\% trocânter do fêmur mais anterior em relação ao acrômio, 97,3\% assimetria da pelve e 70\% joelho em flexão. Ao compararmos os dois grupos, através do teste Mann-Whitney, observou-se diferença significativa no ângulo frontal do membro inferior esquerdo, ângulo $Q$ direito, trocânter do fêmur anterior em relação ao acrômio e ângulo da cifose torácica. Conclusões: Foi possível concluir que as principais alterações posturais encontradas foram a anteriorização da cabeça, assimetria horizontal da pelve, assimetria vertical do tronco e joelho varo. Destacou-se que o grupo da hidroginástica apresentou maiores desalinhamentos. Com esses resultados, é possível promover métodos preventivos às alterações posturais e, assim, diminuir o impacto negativo que esses desalinhamentos provocam na vida idosos.

Palavras-chave: Idosos; Postura; SAPO.

Agradecimentos: PROSUP / CAPES. 